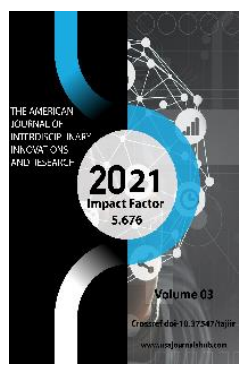

\title{
Socio-Psychological Factors Influencing The Formation Of Leadership Qualities In The Student Community
}

\author{
Mardieva Shakhnoza Amirovna \\ Psychology Teacher At The Samarkand State Institute Of Foreign Languages, Samarkand, \\ Uzbekistan
}

\begin{abstract}
Journal Website: https://theamericanjou rnals.com/index.php/ta jiir

Copyright: Original content from this work may be used under the terms of the creative commons attributes 4.0 licence.
\end{abstract}

\section{ABSTRACT}

This article of training sessions is designed to educate responsible, proactive, creative, purposeful leaders. The article is focused on identifying and realizing the leadership potential of a teenager. Information will be able to help students more fully and objectively realize their leadership potential and ways of its development in the framework of personally and socially useful activities.

\section{KEYWORDS}

Socio-Psychological Factors, Leadership, Student Age, Emotional Leader, Leader-Critic, LeaderOrganizer, Leader-Executor.

\section{INTRODUCTION}

Learning interaction, taking into account the psychological characteristics of each age group, creates self-awareness in a person. The earlier a child wakes up with a sense of selfawareness, the sooner he will have a personal point of view, a sense of his own behavior, an assessment of his practical and physical capabilities. At the same time, there is a mental barrier to the formation of such vices as whim, stubbornness and stubbornness. Conflict in interpersonal relations is the result of indifference to the laws of the development of the crisis. Despair in the human psyche is the product of a disproportionate marriage with the theory of changing the spirit of the struggle for social justice. The formation of beliefs, worldviews, attitudes, communication, independent behavior in people depends more 
on the factors listed above. It is advisable to identify the initiative and desire of people to overcome obstacles and give them psychological motivation, based on the characteristics of educational psychology.

\section{THE MAIN PART}

In general, the use of educational psychology in the family, upbringing, institutions, industrial enterprises and public organizations in all spheres of public life is the key to establishing positive interpersonal relations in the field of education and upbringing, increasing production efficiency. In order for all educational institutions in the country to organize education on a correct, scientific basis, it is necessary to know the specific psychological laws of this process, its mechanisms, as well as effective ways of structuring the process of active, independent and creative thinking. based on modern knowledge.

As you know, sustainable development and prosperity of any country depends on the human factor, in particular, on the scientific, creative and spiritual potential of the younger generation. In this regard, it is important to ensure the effectiveness of youth policy in our country, where the majority of the population is young people. Today in Uzbekistan all the necessary conditions are being created for young people to realize their noble goals. Youth issues are addressed at the level of state policy. On June 30, 2017, a new page was opened in the life of the youth of our country. On the initiative of the President of the Republic of Uzbekistan, the Youth Union of Uzbekistan was created, the main activity of which is aimed at supporting and implementing all youth initiatives. It should be noted that in the current era of globalization, the worldview of youth is changing day by day. Today it is becoming increasingly difficult to design projects that will surprise young people and take root in their hearts. One of the main reasons for this is the active use of modern information communications, their ability to keep abreast of world news and events.

Leadership is a desirable goal for many. The leader is respected, listened to his comments and advice, try to imitate him and be friends with him. Modern society requires a person to have such qualities as decisiveness and purposefulness, which, together with other skills, form a leader in a person. Society requires its citizens to have an "active civic position", which implies, among others, the presence of their own opinion and the ability to defend it; determination in achieving the set goals, striving forward. The presence of such a position in a person is a manifestation of the "leadership" qualities of a person. The secret of developing leadership skills lies in the success of children, their sense of their growth and movement forward. Children love being a winner. But when faced with difficulties and setbacks, they can experience negative emotions of frustration and fear. Our task is to show children that everyone can develop and improve their leadership potential. The main thing is to determine the field of activity for the best application of your strength and achievement of success. In adolescence, a person develops a need for cooperation with people, for strengthening ties with his social group, for manifesting a sense of unity and cooperation. 
The topic of the development of students' leadership qualities in a general educational organization is becoming more and more relevant in the modern world, since the formation of their personality and active life position largely depends on this. The requirements imposed by society on the younger generation imply the presence of leadership qualities, since not only effective management of industrial and public enterprises depends on this, but also the successful self-management of those who will work for them. This is one of the state tasks. Serious changes have occurred in general educational organizations, therefore, especially high requirements are imposed on its graduates: initiative, perseverance, faith in oneself and the success of a common cause. It is necessary to be able to organize oneself and one's work, to overcome obstacles of an internal and external nature on the way of increasing its efficiency.

Student age is an extremely important period in the formation of personality. During this period, there is an expansion of living space, social environment. The development of students' leadership qualities is clearly expressed: already in universities it is clear which of the students reveals their inner potential or at least tries, and who does not see the need for it at all. It is good if the child strives to be a leader, to be the first in his company.

A leader is an authoritative person who is trusted in the team, whose opinion is taken into account and allows making decisions for the whole team. No one appoints or elects a leader; he appears in the course of the development of relations in a team. The leader makes decisions, leads the entire team, feels the mood of others, participates in resolving conflicts, bears greater responsibility for his actions than other people in the team. The team trusts him. Let's talk about how to become a leader in a team, and first find out how you understand who a leader is (learning answers).

In psychology, it is customary to distinguish between the following types of leaders.

- Emotional leader - knows how to build friendly relationships with different people in the team;

- Leader-critic - is able to critically analyze a project or situation, highlighting their strengths and weaknesses;

- Leader-intellectual - knows how to produce various positive ideas;

- Leader-organizer - knows how to plan the performance of work and distribute responsibilities among the participants;

- Leader-executor - knows how to clearly and in due time to fulfill the duties assigned to him;

All this requires the presence of certain qualities, including courage, representativeness, the ability not to deviate from the set goal, intelligence, energy, analytical skills, self-confidence, organizational skills, strong will.

The concept of leadership exists in sociology, political science, psychology and other sciences about man and society. The study of this phenomenon has a direct practical orientation. This is essential for the development of effective leadership methods and for the selection of leaders. Leadership as a social phenomenon is based on certain 
objective needs of complexly organized systems: in self-organization, ordering the behavior of individual elements of the system in order to ensure its vital and functional ability [1].

The Leader Trait Theory states that people are born leaders. There are certain innate properties and characteristics of a person, such as the strength and mobility of nervous processes, extroversion, the ability to empathy - sympathy, pronounced heuristic and intellectual abilities, which enable him to take a leading position in any situation and take on the role of a leader [2, p.94].

But in real life, many cases, people with great leadership potential did not become leaders. Jennings. E. believes that in almost every group there are members who are superior to leaders in intelligence, abilities, but do not have leadership status [3].

Research on leadership, organized by N. S. Zherebova, proved that a specific field of activity, for example, studies, socially useful work, etc., offer their instrumental (situational) leader. Similar data were obtained in a study carried out under the leadership of V.V. Shpalinsky. When studying student and labor collectives, as a rule, different people turned out to be leaders in the four named areas. Complete coincidence of leaders in one person occurred only in isolated cases. Accordingly, the definition of a leader put forward by $B D$ Parygin deserves special attention: "A leader is a member of a group who spontaneously promotes to the role of an unofficial leader in a certain, specific, usually sufficiently significant situation to ensure the organization of joint collective activities of people for the fastest and most successful achievement of a common goal "[4, p.173].

Leadership is one of the ways to differentiate a group as a result of activities, communication and interaction of its members. It appeared as a result of communication and interaction of individuals within a group. Leadership is also a complex socio-psychological phenomenon in which the most important characteristics of group development are focused and manifested, which have a psychological, social and class essence. Thus, leadership is a complex socio-psychological process of group development, as a result of which the group structure arises and differentiates, its optimization and continuous improvement occurs. There are various types of leadership in the psychological literature. For example, distinguish between "formal" and "informal" leadership. "Formal" leadership is associated with established rules for the appointment of a leader and implies a functional relationship. "Informal" leadership emerges from the personal relationships of the participants. This is the so-called nature of leadership [5].

Becoming a leader and developing a group is a continuous and non-separable process. The leader is also the status of a person in a group. And the status of a certain person is subject to change. As a result of interpersonal relations, the status of each of its members is determined and at the same time their influence on the group is determined. Personality is a relatively stable integral system of intellectual, moral-volitional and sociocultural qualities of a person, expressed in the individual characteristics of his consciousness and activity. Personality traits are complex socially and biologically determined structural 
components of a personality that incorporate mental processes, properties, formations, stable states and predetermine the stable behavior of a person in a social and natural environment [6].

According to a number of studies, about 70 leadership qualities have been identified. But to form such a number of qualities is an impossible task. Accordingly, it is important to choose the most important ones correctly, following the Pareto principle of $20 \%$, which will influence $80 \%$ of becoming a leader. As a result, 12 main leadership qualities were identified. They were conditionally divided into 3 groups: systemic, communicative and internal. Systemic: vision, goal-setting, dedication or perseverance, flexibility. Communicative: sociability, ability to motivate and inspire, organization, support.

Moving towards a goal, a leader must be flexible. This is the ability to own a large arsenal of strategies and choices. This makes it possible to act most effectively in each specific situation. One of the varieties of flexibility of mind and actions is the ability to go beyond the system. Flexibility can also be attributed to leadership ability [30]. In the modern world, the value of communication is very high. This quality is relevant not only for the leader, but for modern people in general. The ability to communicate well with the people you need is the key to the success of any business. The main components of sociability: the ability to quickly establish contact, have an interlocutor, listen and hear, the ability to ask questions and receive information. Sociability makes it possible to organize the necessary contacts and connections at the right time to more effectively achieve the goal. In the modern world, this is called networking. Thus, this quality, due to its special importance, must be distinguished.

Self-esteem - a person's attitude to their abilities, capabilities, personal qualities, as well as to their appearance. It can be correct (adequate) when a person's opinion of himself coincides with what he really is. In those cases when a person assesses himself biasedly, when his opinion of himself is sharply at odds with what others think he is, self-esteem is most often wrong, or, as psychologists call it, inadequate. If a person underestimates himself in comparison with what he really is, we say that he has low self-esteem. In the same cases, when he overestimates his capabilities, performance results, personal qualities, appearance, he is characterized by increased self-esteem [7].

The ability of a person to show leadership largely depends on self-esteem. A person may have leadership potential, he may have the qualities of a leader, but they may not manifest due to low self-esteem, since a person with low self-esteem is most often afraid of being misunderstood and rejected. Leadership traits theorists believe that a prerequisite for recognizing a person as a leader is the possession of specific leadership traits and abilities. Research conducted in line with this theory has focused on identifying qualities specific to leaders. A variant of this approach is the charismatic concept of leadership, according to which leadership is bestowed upon individuals as a kind of grace ("charisma"). Charisma is the inner glow of a person, forcing the people around him to follow him. This is self-confidence, charm [8]. 
The leader must be active in every way. He tries to go half a step ahead of time. He needs to have the latest information and be at the center of the flow of events in order to act first. In the modern world of huge speeds, delay threatens to lose both in moral and financial terms, which ultimately turns into lost profits. As soon as the goal is set, the movement begins, and then it is necessary to control the entire system based on key parameters in the direction of movement. Thus, this quality must be explored through the study of self-esteem. Self-control is a quality that every leader should possess. The concept of self-control includes a number of qualities such as resistance to stress, the ability to take a blow, self-control, which are associated with critical situations and the manifestation of negative emotions [30]. This quality can also be conditionally attributed to leadership abilities. Thus, summarizing the above, we can draw the following conclusions. Personality traits are complex socially and biologically determined structural components of a personality that incorporate mental processes, properties, formations, stable states and predetermine the stable behavior of a person in a social and natural environment. Leadership personality traits are as follows: systemic (vision, goalsetting, perseverance, flexibility), communicative (communication skills, ability to motivate and inspire, organization, support), internal (inner integrity, confidence, proactivity, self-control)

\section{CONCLUSION}

Leadership personality traits are as follows. Systemic: vision, goal-setting, perseverance, flexibility. Communicative: sociability, ability to motivate and inspire, organization, support.
Internal: internal integrity, confidence, proactivity, self-control. The most effective methods for the development of leadership qualities of 60 high school students will be: practical, problematic, research, heuristic. The most relevant for the development of leadership qualities of high school students will be: psychological trainings, participation in promotions, participation and preparation for events, the development of social projects. A social project is a model of human activity aimed at changing a particular social situation, overcoming various social problems in education. the younger generation. Correctly organized socio-psychological training develops important traits of human personality, contributing to self-improvement and personality development, aimed at the formation of leadership qualities in high school students. The educational results of the development of the leadership qualities of high school students can be conditionally divided into three levels: the acquisition of social knowledge about leadership abilities in general, as well as about their own leadership potential and the need for its development and the possibilities of using them in socially useful activities; the student gaining social experience in the application of leadership qualities in socially useful activities in the environment of universities; schoolchildren gaining experience of independent social action in an open social environment.

\section{REFERENCES}

1. Ann L.F. (2006). Psychological training with adolescents. SPb.: Peter,. 271p.

2. Makartycheva G.I. (2008). Training for adolescents: prevention of antisocial behavior. SPb.: Rech,.192p. 
3. H.E. Rudyakova. (2008).

Psychocorrectional work with high school students: trainings. Volgograd: Teacher, 99p.

4. Ananiev B.G. (1996). Psychology and problems of human science. ed. A. A. Bodaleva. M.: Publishing house "Institute of Practical Psychology". 384

p.

5. Gromyko Yu. V. (2000). Concept and project in the theory of developing education. Izv. Russian acad. education. No. 2. P. 36-43.

6. Kobzeva N.I. (2011). Age and sociopsychological portrait of the modern student of the educational process of the university. Modern studies of social problems: electronic scientific journal. No. 4 (08).

7. Kon I.S. (1984). In search of himself: personality and its self-awareness. M., Education. 324 p.

8. Miller M. (2005). Where does the leader begin. M.: Phoenix. $232 \mathrm{p}$.

9. Mitina L.M. (1997). Personal and professional development of a person in new socio-economic conditions. Vopr. psychol. No. 4. pp. 28-38.

10. Vygotsky L.S. (1999). Educational psychology.(ed. V. V. Davydov). M.: Pedagogika-Press. 536 p. 